\title{
Managementul pacientului consumator de droguri intravenoase cu endocardită infecțioasă pe cord drept
}

\author{
Cosmina Gabriela Tănase', Mihnea Casian', Daniela Elena Căldăraru', \\ Ana Maria Rădulescu', Mirela Georgiana Tene' ${ }^{1}$, Violeta Melinte ${ }^{1,2}$ \\ ${ }^{1}$ Universitatea de Medicină şi Farmacie „Carol Davila“, Bucureşti, România \\ ${ }^{2}$ Spitalul Clinic de Boli Infecţioase şi Tropicale „Dr. Victor Babeş“, Bucureşti, România
}

\begin{abstract}
REZUMAT
Introducere. Endocardita infecţioasă pe cord drept (EICD) beneficiază de o menţiune specială în cel mai recent ghid de management al endocarditei infecţoase (EI) al Societăţii Europene de Cardiologie (ESC), prin prisma particularităţilor de epidemiologie, prognostic, complicaţii, management medical şi chirurgical pe care le prezintă (1). Principalul factor de risc pentru dezvoltarea EICD este reprezentat de consumul de droguri intravenoase, comportament ce explică, totodată, creşterea incidenţei EICD în ţările dezvoltate, în rândul populaţiei tinere $(2,6)$.

Materiale şi metodă. Prezentăm cazul unui pacient în vârstă de 25 de ani, consumator de droguri intravenoase (CDI), care se internează în Spitalul Clinic de Boli Infecţioase şi Tropicale „Dr. Victor Babeş“ pentru astenie marcată, febră şi artralgii generalizate, debutate la scurt timp după autoadministrarea de heroină intravenos. Prezentarea clinică sugestivă pentru sepsis şi indice crescut de suspiciune pentru EICD au ghidat investigaţiile paraclinice ulterioare şi terapia antibiotică empirică.

Rezultate. Diagnosticul pozitiv de sepsis a fost stabilit odată cu pozitivarea primei hemoculturi pentru Staphylococcus aureus meticilino-sensibil, în asociere cu un scor SOFA de 4 puncte, iar confirmarea diagnosticului de EICD a venit odată cu descrierea ecocardiografică a existenţei de vegetaţii la nivelul valvei tricuspide, iniţial însumându-se 1 criteriu Duke major şi 3 minore. Evoluţia lent favorabilă a pacientului, dezvoltarea insuficienţei severe de valvă tricuspidă, persistența infecţiei sub antibioterapie şi riscul emboligen crescut calificau pacientul pentru intervenţia chirurgicală cu scop de înlăturare a focarului infecţios şi restaurare a funcţionalităţii aparatului valvular.

Concluzii. În cazul pacientului nostru, acelaşi comportament generator al patologiei, CDI, a determinat şi temporizarea intervenţiei chirurgicale, în condiţii de stabilitate hemodinamică, până la menţinerea unui sevraj de durată la heroină. Pacientul a solicitat externarea la cerere înainte de finalizarea curei antibiotice, reiterând prin aceasta necesitatea abordării EI la CDI de rutină într-o echipă multidisciplinară, care să includă medic infecţionist, cardiolog, chirurg cardiovascular, psiholog, psihiatru şi grupuri de suport, atât pentru creşterea aderenţei la tratament, cât şi pentru scăderea morbidităţii şi mortalităţii de toate cauzele, a riscului de recurenţă a EI şi a reluării CDI.
\end{abstract}

Cuvinte cheie: endocardită infecţioasă, valvă tricuspidă, criteriu Duke, Staphylococcus aureus meticilino-sensibil (MSSA) consumator de droguri intravenoase $(\mathrm{CDI})$, heroină

\section{INTRODUCERE}

Pacienţii cu EI secundară CDI sunt adesea tineri, au în antecedente un cluster de boli infecţioase precum hepatitele cu virus B sau C şi infecţia HIV şi patologii psihiatrice asociate abuzului de substanţe, care sunt adesea complicate de lipsa suportului social şi familial. Complexitatea îngrijirilor necesare unui astfel de pacient impune abordarea multidisciplinară în cadrul unei echipe alcătuite din medic infecţionist, cardiolog, chirurg cardiovascular, psiholog, psihiatru şi grupuri de suport; abordarea unidisciplinară condamnând la eşec eforturile fiecarui specialist în parte (9). Tratamentul EICD vizează antibioterapia intravenoasă, alături de in- 
tervenţia chirurgicală, cu o rată de succes operator iniţial similară în populaţia generală, comparativ cu CDI. Ulterior, rezultatele sunt net inferioare la cei din urmă, fapt datorat în primul rând ratei ridicate de recidivă a consumului de droguri şi riscului de EI a valvelor protetice (2-5). Managementul actual al dependenţei foloseşte o abordare integrativă, combinând atât strategii farmacologice, cât şi nefarmacologice.

\section{EPIDEMIOLOGIE}

În rândul CDI, peste $85 \%$ dintre EI survin la nivelul cordului drept, cu o afectare a valvei tricuspide în peste $90 \%$ dintre cazuri (3). Microorganismele implicate în etiologia EICD la CDI sunt:

- Staphylococcus aureus - cel mai frecvent agent etiologic, coc Gram +, aerob, necapsulat; se poate multiplica la nivelul tegumentelor şi mucoaselor (în special în zonele piloase şi la nivelul vestibulului nazal); $20 \%$ dintre persoanele sănătoase sunt purtătoare în mod permanent de $S$. aureus; în funcţie de sensibilitatea la meticilină, se împarte în Staphylococcus aureus meticilino-sensibil (MSSA) şi Staphylococcus aureus meticilino-rezistent (MRSA).

- Streptococii de grup A, C sau G - EI acută cauzată de aceşti streptococi beta-hemolitici se aseamănă cu cea cauzată de S. aureus, cu complicaţii supurative şi o rată a mortalităţii de 30-70\%;

- Enterococii - determină în majoritatea cazurilor o endocardită subacută; sursele sunt tractul gastrointestinal sau cel genitourinar;

- Germenii Gram-negativi - mult mai rar implicaţi - P. aeruginosa şi grupul HACEK.

În România, primele date privind CDI sunt raportate din anul 1995 şi arătau că 2,7\% dintre tineri încercaseră deja să consume droguri; doi ani mai târziu, procentul a atins $10 \%$ (6). Heroina a fost scoasă pe piaţă încă din anul 1898 de către firma germană Bayer - ca o alternativă la morfină - şi a fost disponibilă timp de 12 ani în tratamentul tusei iritative la copii pentru proprietăţile antitusive (6). În Romania, şi-a făcut cunoscută apariţia abia la câţiva ani de la căderea comunismului ca un drog de nivel superior faţă de aurolac (denumire comercială a unui lac ce conţine solvenţi cu efecte halucinogene odată inhalaţi). Structura de bază de tip morfinic determină majoritatea efectelor pe termen scurt (euforie - din cuvântul german „heroisch“ eroic, consumatorul simţindu-se invincibil, prezentând analgezie, flushing tegumentar, prurit, bradipnee, hipotensiune, greaţă, xerostomie etc.) şi lung (dezvoltarea toleranţei şi a dependenţei uneori chiar de la prima doză, afectarea funcţiei cognitive). Practica administrării heroinei intravenos atrage după sine riscul contractării de infecţii cu transmitere parenterală şi de dezvoltare a unor complicaţii precum: EICD, sepsis, abcese, flebite la locul injectării etc. (7).

Conform raportului de ţară privind drogurile, pentru România, 3,9\% dintre tinerii cu vârste cuprinse între 15 şi 34 de ani au consumat în 2016 cel puţin o dată droguri, iar al doilea cel mai utilizat drog este heroina (6).

\section{PREZENTAREA CAZULUI}

Un pacient în vârstă de 25 de ani, din mediul urban, se prezintă la Spitalul Clinic de Boli Infecțioase şi Tropicale „Dr. Victor Babeş“, Bucureşti, pentru astenie marcată, febră $\left(38^{\circ} \mathrm{C}\right.$ înainte de administrarea de antipiretice la domiciliu) şi artralgii generalizate, debutate cu 4 zile anterior prezentării, la scurt timp după cea mai recentă autoadministrare de heroină intravenos, la nivelul venei femurale stângi. Din istoricul de comportamente patologice ale pacientului menţionăm: uz curent de heroină intravenoasă (de aproximativ 8 luni), fumător ocazional canabis (de aproximativ 6 ani), uz de scurtă durată de etnobotanice administrate intravenos, în urmă cu 10 ani, uz singular de LSD (dietilamida acidului lisergic), fumător de tutun (10 PA), neagă consum alcool. Pacientul s-a prezentat cu o stare generală alterată, conştient, cooperant, tahicardic (110 bătăi/min), hipotensiv $(100 / 65 \mathrm{mmHg})$, tahipneic (24 respiraţii/min), subfebril $\left(37,6^{\circ} \mathrm{C}\right.$ axilar). La inspecţie s-au decelat numeroase tatuaje, cicatrici la locurile de puncţie venoasă, edentaţie parţială, iar restul examenului obiectiv a pus în evidenţă ca unic element patologic prezenţa de raluri crepitante diseminate bilateral, simetric, fără sufluri cardiace sau carotidiene.

Prezentarea clinică sugestivă pentru sepsis cu punct de plecare pulmonar (scor qSOFA 2 puncte) şi un indice crescut de suspiciune pentru EICD (2 criterii Duke minore - CDI, febră) au ghidat 
terapia antibiotică empirică cu vancomicină 1 g/12 h iv. şi meronem $1 \mathrm{~g} / 8 \mathrm{~h}$ iv., la care s-au adăugat tratamentul igienodietetic, patogenic şi simptomatic pentru sindromul de sevraj la heroină. Cele două diagnostice prezumtive au fost confirmate odată cu pozitivarea primei hemoculturi pentru MSSA, în asociere cu un scor SOFA de 4 puncte, respectiv cu descrierea ecocardiografică a existenţei de 3 vegetaţii la nivelul valvei tricuspide anterioare, iniţial însumându-se 1 criteriu Duke major şi 3 minore. Investigaţile paraclinice au relevat leucocitoză cu neutrofilie, anemie microcitară, hipocromă, trombocitopenie severă, valori ale proteinei $\mathrm{C}$ reactive (PCR) şi ale procalcitoninei de peste 50 de ori mai mari decât limita maximum admisă. Imagistic s-au stabilit diagnosticele de bronhopneumonie şi minime pleurezii bilaterale, moment în care se ia în discuţie o legătură de cauzalitate între aspectul şi dimensiunile vegetaţiei valvulare şi aspectul imagistic pulmonar, cu suspiciunea infarctelor pulmonare septice. Serologia pentru HIV1/2, VHB, VHC este negativă. În procesul de prevenire a transmiterii infecţiilor parenterale, un rol important îl are programul de împărţire gratuită a seringilor de unică folosinţă CDI, de care pacientul a afirmat că a beneficiat. În România, sunt împărţite la nivel naţional peste 1,4 milioane de seringi/an (6). Anemia microcitară, hipocromă (Hb minimă $7 \mathrm{~g} / \mathrm{dl})$ şi sideremia scăzută au condus la diagnosticul de anemie feriprivă, cel mai probabil prin deficit de aport şi cu siguranţă accentuate în context infecţios, astfel încât pacientul a beneficiat de transfuzia a 2 unităţi de masă eritrocitară. Rolul CDI în patogenia anemiei merită menţionat, pe de-o parte prin efectul nervos central al heroinei, apărând inapetenţa, greaţa, şi, pe de altă parte, pentru că ne confruntăm cu un tânăr nesalariat, fără venituri stabile, condamnat practic la malnutriţie prin deturnarea fondurilor către procurarea heroinei şi a tutunului.

În ciuda antibioterapiei cu spectru larg, pacientul a alternat perioade de normotermie cu pusee febrile şi a menţinut nivelul leucocitelor şi al proteinei $C$ reactive la valori crescute, în platou, pe parcursul celor 42 de zile de internare. Au fost recoltate probe serologice suplimentare - IgM Coxiella burnetii negativ şi IgM Chlamydia pneumoniae negativ - şi hemoculturi adiţionale, însumând 5 hemoculturi, dintre care 3 pozitive pentru MSSA sensibil la cloramfenicol, gentamicină, oxacilină, penicilină $G$, tetraciclină, linezolid şi rifampicină. Ultima hemocultură negativă s-a înregistrat cu 15 zile anterior externării. Persistenţa infecţiei în aceste condiţii a determinat escaladarea terapiei antibiotice prin adăugare de biseptol $480 \mathrm{mg}$ x2/zi po şi doxiciclină $100 \mathrm{mg}$ x2/zi po şi înlocuind meronem cu tazocin 4,5 g/8 h iv. Prima ecocardiografie transesofagiană efectuată a decelat 3 vegetaţii gigante ataşate valvei tricuspide - dimensiune maximă 29/1 2 mm, regurgitare tricuspidiană moderată, cavităţi drepte nedilatate, FEVS şi funcţia sistolică globală păstrate. Monitorizarea prin ecocardiografie transtoracică a evidenţiat diminuarea progresivă a dimensiunilor vegetaţiilor în paralel cu înrăutăţirea aspectului radiologic şi creşterea progresivă a dimensiunilor opacităţilor pulmonare, întărind suspiciunea că mecanismul de producere a acestora este infarctizarea pulmonară septică. Conform recomandărilor de management al EICD (fig. 1), în urma consulturilor de chirurgie cardiovasculară s-a stabilit indicaţia de intervenţie chirurgicală pe baza persistenţei infecţiei sub antibioterapie, a determinărilor pulmonare embolice, a riscului emboligen restant şi a disfuncţiei valvulare severe.

Intervenţia a fost temporizată până la menţinerea unui sevraj de durată la heroină. Pacientul a fost externat la cerere, după 42 de zile de spitalizare, după 7 zile de afebrilitate, cu PCR şi leucocite la un nivel staţionar de $9 \mathrm{mg} / \mathrm{dl}$, respectiv $13.000 / \mu \mathrm{l}$, cu vegetaţii restante, cu motilitate proprie, de dimensiuni maxime 8,6/9,2 mm, regurgitare tricuspidiană moderat-severă, potenţial complicată cu prolaps de cuspă anterioară.

\section{DISCUTุII}

EICD reprezintă $5-10 \%$ din totalitatea cazurilor de EI şi se întâlneşte predominant în rândul pacientilor CDI. În general, prognosticul EICD este unul favorabil comparativ cu cel al EI de cord stâng, ca atare, abordarea terapeutică a acestei patologii poate fi sistematizată astfel: management conservator în $70-80 \%$ dintre cazuri şi chirurgical în 20\% dintre cazuri. Consecutiv unui număr mic de pacienţi vizaţi incluşi în studii tip meta-analiză, în prezent nu există ghiduri clare referitoare la momentul optim al indicaţiei de intervenţie chirurgicală comparativ cu managementul EI de cord stâng. Majoritatea studiilor actuale indică următoarele criterii: 


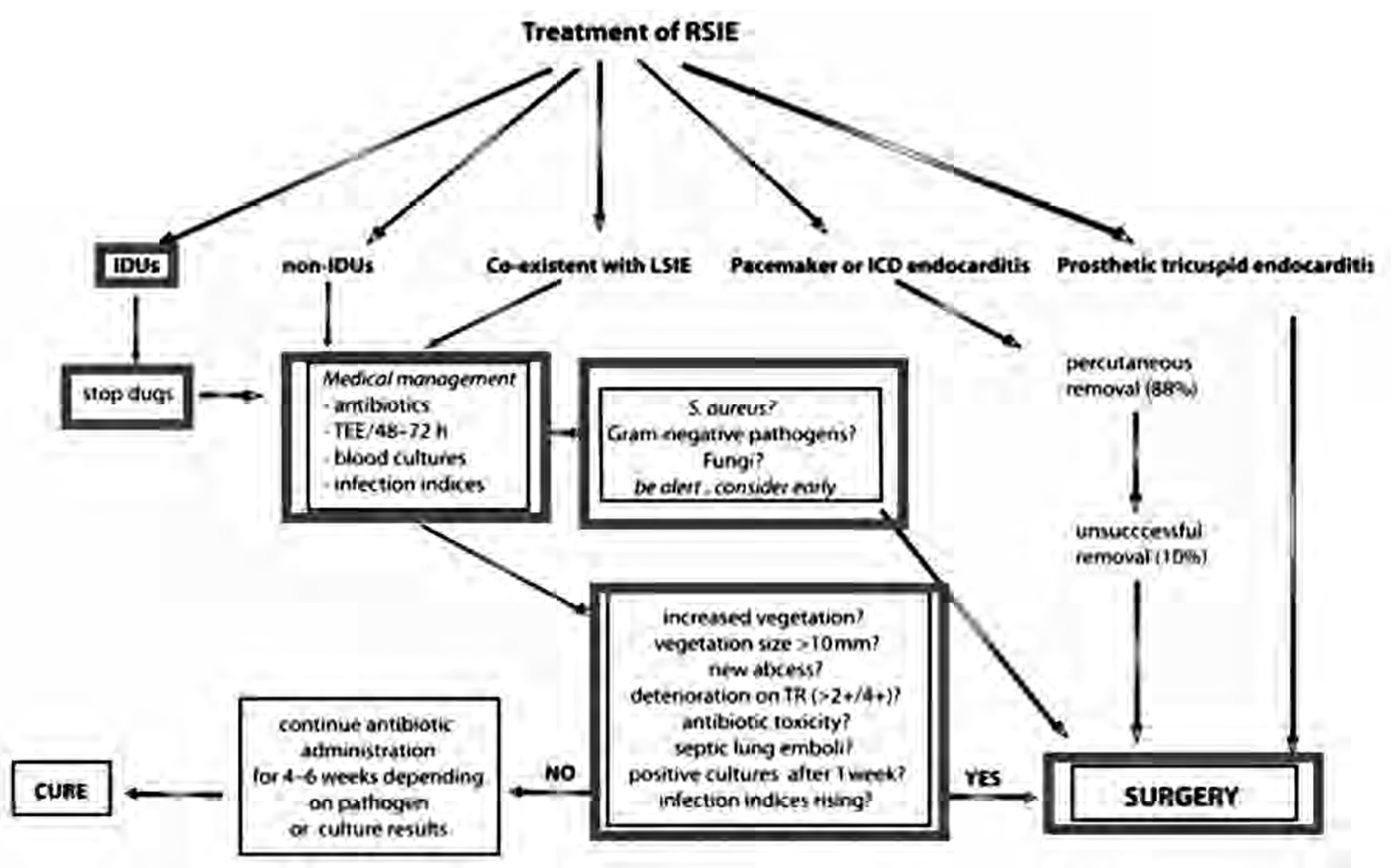

FIGURA 1. Managementul EICD, după Akinosoglou et al. (5)

- insuficienţă cardiacă consecutivă insuficienţei tricuspidiene severe,

- infecţie persistentă sub antibioterapie, emboli septici pulmonari, şoc septic,

- risc emboligen - persistenţa vegetaţiilor cu dimensiuni mai mari de $1 \mathrm{~cm}$ la nivelul valvei tricuspide sub antibioterapie.

Infecţia cu MSSA sau MRSA impune luarea în calcul a intervenţiei chirugicale din faze precoce, adiţional terapiei antibiotice, deoarece se asociază cu existenţa unor vegetaţii de dimensiuni semnificative, valvulopatie cu disfuncţie severă, implicit cu mortalitate crescută (6). Un studiu recent tip meta-analiză atestă faptul că tratamentul conservator în cazul infecţiei cu S. aureus a fost asociat cu o mortalitate semnificativ crescută, $51 \%$, comparativ cu tratamentul combinat conservator şi chirurgical $-31 \%(8)$.

\section{CONCLUZII}

Managementul acestui pacient cu EICD, care întruneşte criteriile pentru stabilirea indicaţiei de intervenţie chirurgicală, se distinge prin abordarea particulară adaptată condiţiei de CDI şi riscurilor celor ce derivă, aferente intervenţiei chirurgicale, dintre care cele mai semnificative fiind complianţa redusă la tratamentul anticoagulant postplastie/protezare valvulară şi EI recurentă în contextul continuării CDI, cu indicaţie de reintervenţie chirurgicală şi prognostic prost. Având în vedere stabilitatea hemodinamică a pacientului şi evoluţia lentă a EICD spre insuficienţă cardiacă, se permite temporizarea intervenţiei chirurgicale în vederea consilierii psihologice pentru renunţarea la CDI, element esenţial în evoluţia favorabilă a pacientului. În acest interval de timp, se impun finalizarea tratamentului antibiotic (4 săptămâni de la ultima hemocultură negativă) şi educarea pacientului pemtru profilaxia bacteriemiilor tranzitorii (ex. prin manevre stomatologice).

Pacientul cu EI necesită o abordare integrativă, într-o echipă multidisciplinară ce poate asigura succesul terapeutic. Se ridică astfel ideea implementării conceptului de Endocarditis Team (9), mai ales în rândul pacienţilor CDI. 


\section{BIBLIOGRAFIE}

1. ESC Guidelines for the management of infective endocarditis: The Task Force for the Management of Infective Endocarditis of the European Society of Cardiology (ESC). Endorsed by: European Association for Cardio-Thoracic Surgery (EACTS), the European Association of Nuclear Medicine (EANM), European Heart Journal, Volume 36, Issue 44, 21 November 2015, Pages 3075-3128, https:// doi.org/10.1093/eurheartj/ehv319.

2. Yanagawa B, Bahji A, Lamba W, Tan DH, Cheema A, Syed I, Verma $\mathrm{S}$. Endocarditis in the setting of IDU: Multidisciplinary management. Curr Opin Cardiol. 2018 Mar;33(2):140-147. doi: 10.1097/ HCO.0000000000000493.

3. Kim JB, Ejiofor JI, Yammine M et al. Surgical outcomes of infective endocarditis among intravenous drug users. J Thorac Cardiovasc Surg 2016; 152:832-841.e1.

4. Shetty N, Nagpal D, Koivu S, Mrkobrada M. Surgical and medical management of isolated tricuspid valve infective endocarditis in intravenous drug users. J Card Surg 2016; 31:83-88.

5. Karolina Akinosoglou, Efstratios Apostolakis, Nikolaos Koutsogiannis, Vassilios Leivaditis, Charalambos A. Gogos. Right-sided infective endocarditis: surgical management. European Journal of Cardio-Thoracic Surgery, Volume 42, Issue 3, September 2012, Pages 470-479, https://doi.org/10.1093/ejcts/ezs084.

6. Observatorul European pentru Droguri şi Toxicomanie. Raportul european privind drogurile 2017: Tendinţe şi evoluţii. Oficiul pentru Publicaţii al Uniunii Europene, Luxemburg.

7. Rook EJ, van Ree JM, van den Brink W, Hillebrand MJ, Huitema AD, Hendriks VM, Beijnen JH Pharmacokinetics and pharmacodynamics of high doses of pharmaceutically prepared heroin, by intravenous or by inhalation route in opioid-dependent patients. Basic Clin. Pharmacol. Toxicol. 2006, 98 (1): 86-96.

8. Daniel J Sexton, Vivian H Chu. Infective endocarditis in injection drug users. UpToDate. Retrieved April, 24, 2019, from https://www. uptodate.com/contents/infective-endocarditis-in-injection-drug-users.

9. Habib G. State of the Art: The endocarditis team - a new paradigm. Retrieved April 24, 2019, from https://esc365.escardio.org/Congress/ ESC-CONGRESS-2017/Demystifying-endocarditis/155528-state-ofthe-art-the-endocarditis-team-a-new-paradigm. 